\title{
The Making of an Intellectual: Orlando Fals-Borda, 1948-1958
}

\author{
Juan Mario Díaz / University of Sheffield, UK
}

In 1969, James J. Lamb invited Fals-Borda to be part of the Board of Trustees of the Centre for the Study of Development and Social Change, Massachusetts, USA, to which Fals-Borda reply: "Dear Jim: I have been trying to disattach [sic] myself from portions of the North American heritage which I had received, and with which I find myself increasingly at odds" (FOFB. Digital. Relaciones_Internacionales, Europa_II_Suiza_05).2 As the letter goes on, Fals-Borda explained that: "For this reason I cannot identify myself with any institution of the United States that would uphold or sustain the present economic and social policies pursued toward the nations of the Third World" (FOFB. Digital. Relaciones_Internacionales, Europa_II_Suiza_05).

What portions and to what extent he wanted to detach himself from them is a question that has been only recently examined (Díaz 2007), which, in turn, gave way to a critical view of a number of analyses that divide Fals-Borda's career into clear-cut sequential stages. Gonzalo Cataño, for instance, suggested three phases and Melciades Vizcaíno used three rather vague labels. ${ }^{3}$ Pereira Fernandez adopted a "before and after" Fals-Borda's commitment to theories of modernisation and US developmental policies. As Pereira argues, "[Fals-Borda] gradually abandoned those approaches and began a new intellectual career marked by an autonomous and politically radical perspective" (Pereira 2008, 376).

The approach adopted in this article is more in accord with J. M. Rojas Guerra's words in the preface of Fals-Borda's Anthology: "Las contribuciones de [Fals-Borda] al conocimiento científico de nuestra realidad social son claramente ilustrativas de la metáfora que se utiliza para representar la dialéctica: la espiral, o la circularidad siempre abierta, que nunca se cierra" $(2010,10)$. Indeed, the image of an ever-open spiral seems to be in tune with Fals-Borda's understanding of his own work. In a letter to Tomás Ducay and his wife, Mary, from Geneva, 1968, Fals-Borda, telling his friends about his lectures at London University, wrote: "Son elaboraciones de mis viejos temas subversivos ... según veo, están recibiendo aplicación en Europa antes que en Colombia."4

By looking at Fals-Borda's involvement with the functionalist school in a new light, this article argues that Fals-Borda's "old subversive topics" (more easily recognised after his commitment to the peasant struggle for land in Cordoba, Colombia, in the early 1970s) can be better understood if they are analysed against the backdrop of his personal and professional motivations to become a sociologist. Accordingly, this article looks at Fals-Borda's formative years in the US and at his employment and projects in Colombia between 1948 and 1958. It follows a narrative approach because not only historical sequence dictates its structure but also its ultimate aim is to let the young Fals-Borda's voice be heard. This approach has greatly profited from my access to hundreds of Fals-Borda's original archival documentation. These include correspondence with his family, friends, colleagues and tutors in the US and Colombia. In particular, letters to and from Lynn Smith, the tutor of his doctoral research at University of Florida, with whom Fals-Borda cultivated a long-life friendship and discussed at length his project in the rural community of Saucío. ${ }^{5}$

\section{From the Military Academy to Musical Sociology}

In 1942, Fals-Borda left his home in the Caribbean city of Barranquilla to enter the Military School in Bogotá. His marks were not good enough to allow him to be promoted to the Military Academy, but promotion was possible due to the influence of his cousin, the writer Jorge Zalamea Borda, who was President López Pumarejo's private secretary. FalsBorda was put on the short list of candidates. On 5 February 1943, a satisfied Fals-Borda wrote to his family: "Heme aquí, pues, como cadete efectivo del Ejército Colombiano." (Letters from Fals-Borda to his family on 05 and 10 February 1943. FOFB. Doc_Personales, Escuela_Cadetes_42).

Despite Fals-Borda's parents having had to sell a house to defray his expenses at the Academy, and despite his own progress and adaptation to military life, in June 1944 his mother unexpectedly informed him that there was a scholarship available for him to study for his B.A. in the US. María Borda de Fals, a social activist and leading member of the Presbyterian Church, had obtained the scholarship from the Institute of International Education through the US Embassy in Colombia (FOFB. Universidades, Dubuque_08-09). She, however, left to her son the decision of whether to take it or not. Without too much hesitation, Fals-Borda left the Military Academy to undertake his B.A. in English Literature and Sociology at the University of Dubuque, Iowa.

Very little is known about Fals-Borda's years in Iowa; however, on occasion of his graduation, a local newspaper headed: "Latin-American Wins Acclaim," and highlighted that: "Orlando [Fals-Borda]'s record while on the Dubuque 
campus has been most unusual, his interests very diversified." As the newspaper explained:

In October 1944, he came to Dubuque on a missionary scholarship, and he was graduated this June. While here he majored in English and Sociology. In his senior year he was chosen for Who's Who among Students in American Universities and Colleges, a choice based in part upon his widespread activities: President of Pan American Club for two years, member of the International Relations Club, associate editor of the student newspaper,the "Cue", member of the Year Book staff, vice-president of the student Council in 1946, member of the Men's Chorus, and member of the Gospel Team. His interests further included intramural basketball, tennis, swimming and dramatics (FOFB. Universidades, Dubuque_17).

In the picture accompanying the news, alongside with Fals-Borda appear his mother and his brother Jaime who went to the University of Dubuque in summer 1946 to pursue a pre-med course. The note, expressing the reformist optimism of the time, concluded that: "The measure of good-will and friendliness brought by this Colombian family to the Dubuque campus, were it to be multiplied a thousand times, would make the Good Neighbor Policy a living reality" (ACH-UN, FOFB. Digital. Universidades, Dubuque_17).

In 1948, Fals-Borda returned to Colombia to work in the Youth Presbyterian Centre in Barranquilla and soon thereafter, he moved to Bogotá where he worked as director of the choir of the Presbyterian Church. Interestingly, his first approach to la Violencia - the conflict into which the followers of the Liberal and the Conservative parties were dragged which left more than 200,000 civilians dead between 1946 and 1958 - comes from his passion for choral music. It was a polyphonic piece named "Mensaje a Colombia", composed after the assassination of the liberal leader Jorge Eliécer Gaitán in April 1948 - an expression of "incipient musical sociology," as Fals-Borda put it. More than fifty years later, when "Mensaje a Colombia" was played at the First Presbyterian Church of Barranquilla in January 2002, Fals-Borda recalled that this as well as a few others he composed whilst being one of the tenors of the choir of the University of Dubuque, were religious but also inspired by a sense of patriotic duty. Regarding these compositions Fals-Borda wrote: "Las había empezado cuando con mis amigos del Centro Juvenil Presbiteriano sentimos el impacto desastroso de la revolución del 9 de abril [1948]. Con ellas quise combinar las preocupaciones políticas con la esperanza de una intervención superior y divina para sacar a nuestro país de los peligros inminentes. Mi plegaria entonces sigue vigente" (FOFB.Doc_Personales, Iglesia_Presbiteriana_Música_Coral_22-23).
Along the same lines was his short speech when "Mensaje a Colombia" was performed by the Philharmonic Orchestra and the Polyphonic Choir of the National University in May 2003: "En 1948, cuando lo compuse conmovido por la catástrofe del comienzo de la Violencia, esa pieza expresó una esperanza de redención que no pudo tener eco. Tampoco cuando me convertí en sociólogo y junto con respetados colegas, estudié más a fondo tan trágico destino" (FOFB. Doc_ Personales, Iglesia_Presbiteriana_Música_Coral_19). He was referring to the attempts to silence his book La Violencia en Colombia, 1962, the first comprehensive analysis of la Violencia and, as he recalled, "[his] first expression of abandonment of the functionalist model" (Cendales 2005, 24).

The homage that both the Presbyterian Church of Barranquilla (2002) and the National University (2003) paid to Fals-Borda by playing his music were interpreted by Fals-Borda himself not only as acts of reconciliation (since he had left the university in 1969 and was excommunicated from the Presbyterian Church of Colombia in 1972) but also as a recognition of what he called 'his second nature': "Es mucho, pues, lo que mi musicalidad debe a la Iglesia, en lo que puede ser una segunda dimensión de mi persona, tanto o más satisfactoria que la científica; en realidad pienso que la una me ha ayudado con la otra, si analizamos las estructuras multivocales de algunas de mis obras" $(2009,26)$.

Despite Fals-Borda's passion for choral music, the job as director of the choir of the Presbyterian Church was only temporary since soon thereafter he engaged in what was his first short job as sociologist, as I will explain next.

\section{Fals-Borda's Early Declaration of Values and the "New Generation"}

In April 1949, after offering his service to the Ministry of Education, Fals-Borda was appointed as researcher on a social project of the Instituto de Antropología Social in the small town of Vianí - a pilot project of community development funded by UNESCO. "The minister said," Fals-Borda wrote to his mother, "they were going to appoint me as the person in charge of the archives, because there were many disordered papers in that office" (FOFB. Doc_Personales, Instituto_Antropología_Social_Colombia_04). This is how he recalled it more than fifty years later:

[There was] a problem: my boss told me I shouldn't establish any contact with the people in the village ... When my boss arrived eight days later, the first thing people told him was that I had established a close relationship with the priest, offering to be his organist for the mass, and that the mayor and I used to go to the bars to drink beer. He saw the organized archive, but he said: You haven't complied with the rules, so I'm going to dismiss you. If you don't want 
to be dismissed, submit your resignation. I was fired from my first position as a sociologist after 20 days because I had established contact with the people. This was really the beginning of my sociological career (Cendales 2005, 13).

In the memorandum with the reasons asking Fals-Borda to resign, Gabriel Ospina Restrepo, Director of the Institute, explained that the young sociologist not only disobeyed him but also became a "serious threat to the institute's harmony." This episode, also remembered humorously by Fals-Borda himself, has served to his biographers to emphasise that a people-centred approach was a hallmark of Fals-Borda's career. Much as it was true, what is noteworthy lies behind the anecdote. On 31 May 1949, the 24-year-old Fals-Borda signed a letter of resignation, not without first writing a letter to Ospina Restrepo. The missive was far from being a complaint or a personal recrimination. With the benefit of hindsight, it can be read as a young Fals-Borda's declaration of values. Here are a few relevant fragments:

Quiero por medio de la presente expresarle lo que pienso, con el solo deseo que lo que aquí escriba pueda ser de ayuda y motivo de progreso, ya que todos decimos perseguir un noble fin, cual es el de la redención moral y material del pueblo colombiano. Usted ha hecho una gran labor [...] pero esto no da fundamento a su afán de mantener a la población y funcionarios, bajo un control absoluto. Ninguno de los empleados del Instituto podíamos hablar con los campesinos acerca de lo que más nos interesaba a todos: el proyecto social. [E]s mi opinión que toda cosa buena mientras más conocida es más amada. Si el Instituto es bueno y marcha a su meta con justicia y rectitud, debe soportar por lo menos las preguntas y observaciones de los interesados...

Realmente Ud. ha hecho una gran labor al asegurarse la adhesión de los dirigentes del pueblo, pero no ha alcanzado al pueblo mismo [...] Esto me lleva a pensar que, al menos por ahora, se interesa más por su propio proyecto (la posición en el gobierno y en la sociedad, el tener máquinas, vehículos y empleados, el dar órdenes, etc.) que por el mismo pueblo a quien supone servir. Pueda ser que Ud. en un día no lejano se dé cuenta de la importancia de establecer aquel contacto constructivo y directo con el pueblo que es básico en toda obra social ...

Según he podido observar-y usted mismo me lo ha dicho - en todas partes cree Ud. ver enemigos en potencia que quieren despojarle de lo que Ud. ha alanzado. Usted vive esperando a que sus asociados lo traicionen para tener el gusto de eliminarlos... Sin duda Ud. estará sonriéndose de mi ingenuidad... Pero por favor recuerde que... si el país va a progresar en todo sentido, un movimiento debe comenzar con nosotros los de la nueva generación (FOFB. Doc_Personales, Instituto_Antropología Social_Colombia_01-03).

The tone and the spirit of this letter cannot but recall Walter Benjamin's "Experience," an article published pseudonymously in 1913 when he was 21 years old. "In our struggle for responsibility," says Benjamin, "we fight against someone who is masked. The mask of the adult is called 'experience'. The adult has always already experienced everything ... It was all illusion - often we feel intimidated or embittered. Perhaps he is right. What can our retort be? We have not yet experienced anything." The years of youth, a brief night, will be followed by 'grand experience': the years of compromise, impoverishment of ideas and lack of energy. Such is life. Benjamin's article is an attempt to lift the mask"What has this adult experienced? This", he answered, "the meaninglessness of life. Its brutality." Herein lies the secret, Benjamin said: "because he never raises his eyes to the great and the meaningful, the adult has taken experience as his gospel ... He has never grasped that there is something other than experience, that there are values - inexperienceable which we serve" (Benjamin, 2004, 3).

An exhaustive analysis of Fals-Borda's letter falls out of the purpose of this article. Nor is there space for drawing a parallel of affinities between these two authors. However, looking at Fals-Borda's letter through the lens of Benjamin's "Experience" helps us analyse a key element in Fals-Borda's career: his search for a different (spiritual, socio-political and academic) experience from that that had been bequeathed to him and his generation. In Fals-Borda's own words: "the search for something better" (Díaz 2017, 35-36).

With a reflective tone, Fals-Borda analysed his boss's attitudes one by one - namely, authoritarianism, discrimination, dogmatism, decision-taking based on prejudices and fears, and search of personal benefits - not as individual shortcomings but as a reflection of the vices of the bureaucratic apparatus. This, according to Fals-Borda, came in the wake of the political violence aggravating the social crisis that was impinging upon the "moral and spiritual redemption of the country." Indeed, the death toll had risen to 18,500 in 1949 and by 1951, after the first year of Laureano Gómez's authoritarian regime, more than 50,000 civilians had been killed for political reasons.

Only after his analysis of la Violencia, conducted in 1962, did Fals-Borda grasp the scale of the daunting task his generation carried upon their shoulders. After those years of terror, "the country requires unprecedented efforts and perseverance to produce "something better." "Better," in this sense, wrote Fals-Borda, "refers to the configuration of a new social structure based on the actual application of recognized ideals such 
as justice, respect for life, and encouragement of the creative impulse" $(1964,30)$.

Gravitating around this idea of betterment, we can recognise in Fals-Borda's letter at least three values that he fruitfully developed throughout his career: firstly, his criticism of dogmatism. One of the most consistent tenets of Fals-Borda's intellectual career was that all criticism must be based upon empirical knowledge, not on speculation. As J.M. Rojas pointed out, Fals-Borda responded to criticism of his works with further research. Indeed, Fals-Borda's almost thirty years of trial and error with action research were not only a search for "the better" but also an enduring struggle against deeply entrenched political, religious and ideological dogmatism. It furthermore represented a struggle against functional positivism as a form of scientific dogmatism. "For the researcher, error is only an aid to truth," states Benjamin, "To the one who strives, experience may be painful, but it will scarcely lead him to despair". On the contrary, as Benjamin carries on, the philistine is satisfied with error: "You will never find the truth!" he exclaims to the researcher. "That is the philistine's experience" (2004:3-4).

Secondly, his criticism of any individual or collective attempt to capture the moral high ground based on righteousness and demonisation of the Other-something that his family experienced as liberals and Presbyterians under the Conservative regimes' religious and political intolerance during la Violencia. The figure of la Violencia and the state of cultural and economic stagnation of the rural population discredited that political leadership that boasted of being both enlightened and progressive.

Thirdly, as Fals-Borda recalled it in a conference in the US in 1995, when he posed questions such as how to bring together academic knowledge and ordinary people's wisdom and how this could counter systemic injustice in the 1970s, he was scolded by his former tutors for going astray. The seeds of his understanding of participation as a critique of the asymmetry implied in the subject/object relationship, which also characterised hierarchical orders and traditional social research - part of his commitment to establish genuine and constructive contact with people to carry out social research. This element became increasingly apparent in his first project of social research with the rural community of Saucío, the birthplace of modern Colombian sociology, as will be seen in the next sections.

\section{Winston Brothers Company and the Rural Community of Saucío}

In the light of his resignation, Fals-Borda was offered a transfer to another section of the Ministry of Education. He opted instead to leave. His enthusiasm and eagerness to work were at odds with the bureaucratic ways of the Ministry. As he wrote to his brother Pedro about his resignation: "Ha sido lo mejor que me ha podido suceder [...] ahora sé lo que son los planes sociales del gobierno, sus hombres y sus intrigas. Si hubiera permanecido en Vianí a pesar de todo, hubiera tenido que perder parte de mi personalidad y mi manera de ser, y entrar a hacer prácticas contrarias a mi conciencia" (FOFB. Doc_Personales, Instituto_Antropología_Social Colombia_19). A newspaper advertisement for a bilingual secretary led him to his next job. It was at the Winston Brothers Company, which was building a dam in the canyon of the Sisga River, fifty-six miles north of Bogotá. Soon after, Fals-Borda wrote to Kenneth Wernimont from the American Embassy in Bogotá on 14 June 1949: "I am satisfied with my new work, considering that I have managed to keep myself in contact with the peasants" (FOFB. Doc Personales, Instituto_Antropología_Social_Colombia_18).

Working as the director's assistant, the newly graduated sociologist Fals-Borda started his career as a participant-observer in Saucío, a small neighbourhood near the company camp at Sisga. Soon after, he moved in to Saucío and, for two years, he became fully embedded in the ordinary conditions of life endured by the family who "adopted him". "In Saucío, Fals-Borda performed farm chores and dressed in the typical ruana (a kind of poncho), boots and khaki pants. He even altered his mode of speech so as to eliminate traces of class superiority in his dealing with peasants" (Goulet 1974, 58-59).

Telling his brother about the new job at Winston Brothers Company, Fals-Borda wrote: "En esta forma permanezco en contacto con los campesinos, a quienes deseo conocer mejor antes de emprender ningún proyecto sociológico de mi propia iniciativa" (FOFB. Doc_Personales, Instituto_Antropología Social_Colombia_9). In fact, his job at Winston Brothers Company not only provided him with the contact of a rural community but also make possible for him to carry out an MA in rural sociology at the University of Minnesota. His dissertation, "Peasant Society in the Colombian Andes," in 1953, was a historical and ethnographic-based study of the origins, development and life of the Saucío community. In 1955, when it was published, Fals-Borda, commenting on the innovative approach of and the good reviews on his work, would write to W. J. Rohan "Although the book is scientific, we all expect that it will sell well because it is the first of its kind coming out of Colombia, and in a sense, from Latin America" (FOFB. Digital. Libros, Peasant_Society_Colombia_35-38). ${ }^{6}$

All started in early March 1950, when F. Oclassen, Fals-Borda's boss, was requested to write for the company's magazine, the Winstonian, an item about the Sisga project. A week later, Oclassen replied to headquarters in Bogotá: "Nothing happens in Sisga. No shooting, no killing-the job (is) going on at its steady pace as usual." "However," he went on, "if this old gringo has nothing to write home about, why not let a native express his thoughts. A victim was 
soon found in the person of our secretary-Señor Orlando Fals-Borda. We all like Orlando, an efficient young man with both Colombian and American background ... with the hope of returning to the States for further studies, after the completion of the Sisga job" (FOFB. Documentos_Personales, Winston_Bros_Company_01).

The article Oclassen asked Fals-Borda to write for the Winstonian was front page in April 1950. In it, Fals-Borda expressed his great appreciation of values such as "spontaneous fellowship", "wholesome interchange of ideas and skills," and "efficiency and love of the work" which he regarded as "essential in raising the standard of living of the country" (FOFB. Documentos Personales, Winston Bros Company 02-04). Fals-Borda's article attracted the attention of the company's president, W. J. Rohan, whose impression was, as Fals-Borda was told, that nobody had put Winston Company's mission in such clear and simple terms as he did in his article. Hence, when Rohan visited Colombia, he did not hesitate to offer Fals-Borda a post in the United States so that he could do his MA whilst working in the headquarters in Minnesota. A jubilant Fals-Borda (who had unsuccessfully tried to obtain another scholarship for his MA from the Institute of International Education - from which institute his mother obtained the scholarship for his studies in the US in 1944) wrote to his mother:

El viernes pasado sucedió algo extraordinario, que salvo causas imprevistas puede facilitar enormemente mi regreso a los Estados Unidos. Fue algo inesperado, que vino como caído del cielo, pero que demuestra que Dios no nos ha abandonado, sino que sus caminos, aunque confusos, llevan a metas seguras. La propuesta para mi viaje vino nada menos que del presidente de la Winston Bros. Company, actualmente en una gira por Colombia. (FOFB. Documentos_Personales, Winston_Bros_Company_05).

Fals-Borda only concern was, as he wrote to his mother, how to coordinate the company's aid with his future plans to return to Colombia as a sociologist to contribute toward the need of socio-economic transition in the rural area. This aim so early defined in Fals-Borda's career, from which he did not waver in the face of professional opportunities in the US, is the backdrop against which must be seen what some critics contemptuously call his "positivist stage."

Moreover, the job at Winston Brothers Company not only gave Fals-Borda the opportunity to live within a rural community and set out his own research but it also allowed him to witness and analyse meticulously a process of rapid sociocultural change caused by the overwhelming impact of modern technological development on a pre-capitalist society. Additionally, his work as the all-round director's office man and then as an improvised, though successful, accountant gave Fals-Borda a great deal of managerial experience, from which his later projects profited greatly.

\section{"You are laying the foundations of a sociology in Colum- bia [sic]": 1955-1958}

In 1953, Fals-Borda's plans were to return immediately to Colombia after finishing his MA degree; however, a Guggenheim scholarship gave him the opportunity to complete his $\mathrm{PhD}$ at the University of Florida, where he published his MA thesis in 1955 (ACH-UN, FOFB. Digital. Universidades, Minnesota 18). ${ }^{7}$ After completion of his doctoral thesis "Fragmentation of Holdings in Boyacá, Colombia," Fals-Borda returned to Colombia, where he worked as an assistant chief of socio-economic studies for the Servicio Técnico Agrícola Colombiano Americano (STACA), a joint programme of the US Point IV Program to Colombia and the Ministry of Agriculture. ${ }^{8}$ Despite his expectations, he could not be hired as a rural sociologist 'for the simple reason such a job does not exist at present', a letter from STACA explained (FOFB. Datos Personales, Servicio Técnico Agrícola Colombiano Americano STACA 03). This job, in which he conducted a study to foster colonisation of the western slopes of the Andes in Boyacá, allowed him some time to work on the Spanish edition of his doctoral thesis - published as El hombre y la tierra en Boyacá: bases sociológicas e históricas para una reforma agraria in $1957 .{ }^{9}$

On 15 April 1957, Fals-Borda resigned from STACA to work in cooperation with the Centro Interamericano de Vivienda (CINVA, Inter-American Centre for Housing) as a consultant. Simultaneously, the Office of Social Security of the Ministry of Labour commissioned him to carry out a demographic analysis in four departamentos of Colombia (Antioquia, Cauca, Cundinamarca, and Chocó), which in turn allowed Fals-Borda to fill several notebooks with firsthand information about areas that had been most affected during la Violencia. In February 1958, Fals-Borda went to Brazil to conduct a study on tropical housing (FOFB. Brasil. Correspondencia_Brasil_36-39). This did not stop him from working on the report on the agro-sociological experiment in Saucío that he had started in 1956 (Fals-Borda's letter to Lynn Smith on 10 December 1957; FOFB. Universidades, Florida_67).

This project, which aimed to foster productivity and better standards of living amongst peasant farmers in Saucío, was Fals-Borda's main concern, as his correspondence during this period indicates. Written with an enthusiastic tone, Fals-Borda's letters to his friends and colleagues were full of graphic descriptions about this programme. This enthusiasm also permeated his letters declining professional opportunities in the US. 
The first one, a letter date 6 July 1956, offered him an appointment as lecturer at the University of Dubuque. Consistent with the aim he had set out six years earlier, he explained:

I certainly would like to enjoy the advantages and the great teaching opportunities offered by the University of Dubuque. But I feel morally obligated to continue my present work, a mission for which I have trained and to which I feel that I should devote my life. I owe this loyalty to my country and its people. Thus, I am unable to accept your offer [...] The land problem is Colombia's most urgent [...] as you may see, I am engaged in activities that require some perseverance. It may be difficult, uncomfortable, and perhaps dangerous, but I must keep on pushing (Letter to G. M. Couchman, President of University of Dubuque, and Leo Nussbaun, Dean of the College of Liberal Arts on 12 July 1956; FOFB. Universidades, Dubuque_03).

The project, though incipient, had drawn the attention of some authorities and international scholars, which made Saucío an example of social development in the late 1950s. ${ }^{10}$ Describing the relevance of this programme and how his initial impulse was "picking up momentum", Fals-Borda's letter put in perspective his decision. He also outlined a series of on-going activities:

1) After six years of contact with an agricultural community, I am at last succeeding in channelling social change toward what I feel are progressive outlets. For instance, for the first time in local history farmers have disinfected their seed and practised seed selection in the field; 2) Out of 41 varieties of blight-resistant potatoes introduced by me from Minnesota in 1952, six have survived. But they are the best potatoes in the region. I am supervising the multiplication of this seed; 3) Two months ago, I introduced a scythe for wheat harvesting, in an attempt to displace the ancient and inefficient sickles that the farmers still use. Likewise, other improved farm implements will be tested in an effort to reduce the toil of agricultural tasks and to increase production per capita. I am selecting some of these implements during my present stay in the United States. (FOFB. Universidades, Dubuque_03).

On the positive effects of the technical innovations, including the new type of potatoes, Fals-Borda wrote to his $\mathrm{PhD}$ supervisor Lowry Nelson: "Two of them have been marketed successfully in Bogotá. As these varieties are superior and taste well, they are becoming more and more accepted by the local farmers" (FOFB. Universidades, Minnesota_24; 26).

The second letter was dated on 19 November 1956, this time from John M. Maclachlan, to lecture at Grinnell College,
Iowa. Fals-Borda replied in the same tone as before: "A possibility such as [that] is a great temptation. But I should remain in Colombia doing research and engage in some applied sociology. The latter, as you know, is much needed in view of the rapid growth of this country and perhaps I could aid in smoothing somewhat the transitional stage" (FOFB. Universidades, Florida_76-77). Fals-Borda seemed very excited about the technical innovations, but the project was highly innovative in another respect: the creation of the conditions for the emergence of a new ethos of social action, in which Fals-Borda saw one of the deepest meanings of socio-cultural change. As his letter of 17 February 1958 to Lynn Smith stated in regards to the publication of a study on social change and technical improvement in the rural community of Saucío "I hope that you will like the report, especially for the evidence gathered that these peasants are people with initiative, with potentialities of inventiveness, and able to exercise drive once convinced of the benefits." He concluded: "This is like discovering a gold mine under the dirt: discovering the great potentialities of our people" (FOFB. Universidades, Florida_5).

The discovery that Fals-Borda mentioned was not simply the people's good qualities, which he had already prized in the final chapter of his Peasant Society (1955), but people's potentialities for organised action. ${ }^{11}$ About this process, that he called the "evolutionary stage of a rationalistic impulse of social change' in Saucío $(1959,36)$, he had kept exhaustive records. As he explained in a letter to William F. Ogburn during his stay in the US in the summer of 1956: "I am planning to use schedules in 1960 and to compare results with 1950 results. In this manner I hope to isolate a number of items for which the objective observation made during these intervening years may throw light as to actual process of change" (FOFB. Universidades, Florida_81). ${ }^{12}$ Such a process of evidence-based social research was indeed a breakthrough in the social science in the country. When Lowry Nelson learnt about it, he wrote to Fals-Borda on 15 November 1957: "You are laying the foundations of a sociology in Columbia [sic]" (FOFB. Universidades, Minnesota_27).

\section{The Scientific Knowledge of Social Reality}

A key element in understanding Fals-Borda's dialectic between his personal motivations (utopianism) and his scientific formation (empiricism) might be sought in his dissertation's epigraph: "Think not that in the king's palace you will escape. For if you keep silence at such a time as this, relief and deliverance will arise ... from another quarter ... Who knows whether you have not come for such a time as this?' (1955, vii, ellipses in the original). The lack of confidence in "the king's palace" refers to the circles of the elite, he said, 'unable to meet with intelligence and integrity the challenges that arise from within their society' (1955, viii). Thus, relief 
and deliverance, namely intelligent leadership working on far-sighted policies, will arise from another quarter. ${ }^{13}$

In the late 1950s, a quarter ready to support Fals-Borda's enterprise was a weekly seminar called Tertulia de los Sábados. A small group of intellectuals created it after the programme of Social Science of the Escuela Normal Superior was dismantled by the conservative regimes during la Violencia. Some of its members would be the first lecturers of the School of Sociology founded by Fals-Borda, who also frequented the Tertulia (Jaramillo 2015, 4). Virginia Gutiérrez de Pineda, one of the lecturers of this School, in whose house the meetings were held, remembered that when Fals-Borda returned from the United States he was talking of sociology as a science:

Quería que una élite intelectual, después de una estricta formación teórica, se proyectara sobre el campo de la realidad nacional. Quería que se analizara cada fenómeno social: que se dijera con cifras concretas la angustia tenencial del hombre del agro, se desplegara en cifras su éxodo urbano, se proyectara la nacionalidad en el pasado y en la etnia y se analizaran los factores propicios y negativos al cambio. (Gutiérrez Virginia, speech on 2 April 1966; FOFB. Universidades, Nacional_101).

Before this, sociology's academic institutionalization took place in terms of the so-called Sociologia de Cátedra, that is, as part of other disciplines, mainly philosophy, education and law. Therefore, structural-functionalism was more than a trend: it represented the theoretical and methodological birthplace of professional social sciences in Latin America. For all its shortcomings, structural-functionalism (which demanded validity and reliability similar to those of the exact natural sciences) transformed Latin American sociology into a statistically and methodologically valid subject. Until then it had been stagnating, based on speculation. ${ }^{14}$

Indeed, Fals-Borda's high regard for factual evidence and for impartial verification engulfed all areas of research: from long-term analysis of the historical evolution of land distribution to the observation of individual cases exhaustively analysed and accurately reported - a practice that in his time was very rare. His study on "Costos de Producción Agricola en un Minifundio: Trigo y Ajo" was a rigorous study in which every aspect and stage was meticulously quantified. By drawing a parallel between traditional and the more systematic and technical forms of production, Fals-Borda managed to quantify both the farmers' meagre profits and the losses due to ignorance of techniques, methods and resources then available. The data on agricultural production previously available, as he pointed out, was inaccurate and, above all, omitted the real implication of agrarian production for people's lives. As he wrote in his case study on the costs of production of wheat and garlic in a smallholding:
Hasta hace relativamente poco tiempo había una completa ignorancia en Colombia, y algo de desinterés también, sobre los costos de producción agrícola. Es cierto que se habían compilado cifras de producción agrícola nacional... pero ningún especialista utilizó estos datos como punto de partida para estudios de campo más realistas y detallados (Fals-Borda 2010, 25).

To policy-makers, however, "scientific" agriculture meant "mechanised" agriculture. However, mechanisation was extremely difficult under the circumstances: complex land ownership, colonial methods of cultivation, superstitions, small isolated and fragmented farms plus the rough geographical conditions. In contrast, to Fals-Borda, "scientific" agriculture meant: first, gaining enough understanding of the human dimension of a social reality without which social change is not possible. ${ }^{15}$ By jointly analysing social structure and cultural traditions, Fals-Borda had discovered that behind peasants' resistance to change lay a deep-rooted relationship between man and the land, which he called the peasantry's philosophy of life. Only by taking into account such a concept of life could the peasantry's potentialities be channelled into constructive ends (1955, 245-247).

Second, it meant gradual transition to modernisation of the traditional rural activity enhanced by education. From his observations during the construction of the dam in Sisga, Fals-Borda concluded that an increase in economic benefits (for instance, farmers' greater purchasing power or more free time) would not necessarily improve personal and social development - only an approach based on education, he argued, would succeed in preventing further rural stagnation. His ideas on the role of education were also welcomed by Robert J. Havighurst, from the Committee on Human Development, who requested and defrayed the cost of the translation into Spanish of Fals-Borda's Master's Thesis's chapters 13 and 14 for the UNESCO manual on Society and Education in Latin America. ${ }^{16}$

Almost a decade after Fals-Borda's first contact with the community of Saucío, education appeared to be the means under which the traditional ethos of passivity and submission could be progressively moulded into a more emancipative one-albeit an education able to instil in the people "an earnest desire to get away from the practices that have maintained them poor morally, spiritually, and physically for so many decades" $(1955,81)$. In this vein, the construction of the local school of Saucío became a symbol, in fact a national monument, of such socio-cultural change. Firstly, it was the action of an organised community that used local labour to achieve communal aims; secondly, the first Board of Communal Action in Colombia was established in the facilities of that school in Saucío (Cendales 2005, 25-26). 
On 12 February 1958, Fals-Borda wrote to Lynn Smith: "I am taking up the study [on social change and technical improvement in the rural community of Saucío] with the Minister of Agriculture one of these days, in an attempt to secure more backing for the program. We all feel that we are hitting on a very significant problem" (FOFB. Universidades, Florida_5). In 1959, in spite of his lack of confidence in "the king's palace," Fals-Borda channelled his knowledge of the problems of the rural life into institutional projects. He accepted an appointment as a vice-minister of Agriculture. The ideal of arriving at a "scientific legislation" fostered by an intelligent and skilled leadership able to meet both social problems with integrity and to work on far-sighted policies, which he had envisioned in 1949, proved to be even more relevant one decade later in the aftermath of la Violencia. At the same time, he, along with Camilo Torres, founded the School of Sociology of the National University.

\section{Conclusion: On Fals-Borda's Empirical Utopianism}

I would like to conclude with a few notes on Empirical Utopianism - a provisional concept I introduced in a previous work to describe Fals-Borda's dialectic between idealism and pragmatism (Díaz, 2017). In this article I have looked at a period during which Fals-Borda had more questions than answers - despite, or perhaps due to, his lack of experience he managed to explore with fresh eyes the terra incognita of the Colombian rural world and rose to the daunting challenges of his generation in search for betterment. Despite the importance of this period in Fals-Borda's academic career, his engagement with the positivist functionalism has overshadowed his later contributions to critical thought and practice in the Global South. Prejudices of this sort ignore not only the role of positivism in establishing the bases of the professional sociology in Latin America but also the centrality of empirical knowledge in Fals-Borda's search for a method of both social research and political participation from the early 1970s onwards. Moreover, this prejudice overlooks that Fals-Borda's dialectic between his utopian motivations and his empirical analysis of social reality was epistemological in its most essential sense: a radical rupture with dogmatism, fanaticism, and speculation. These years were for Fals-Borda, using the title of one of Gaston Bachelard's books, the years of "the formation of the scientific mind."

Another decisive element to understanding his intellectual and political career is that Fals-Borda was committed to the reality of the rural population rather than any theory or institution, thereby his early abandonment of functionalism. Therefore, his intellectual life was not the result of theoretical or ideological ruptures but a continuous dialectic between his vocation as social scientist and his determination to foster social change to the benefit of the people of his land. The early synthesis of this dialectic was a unique form of empirical utopianism. With the benefit of hindsight, we can say that Fals-Borda knew something different that the overwhelming experience of the adults could neither have given to him nor taken away - this was his truth to which he owed his fidelity. "The youth will experience spirit," says Benjamin, "and when he becomes a man, the youth will be compassionate. The philistine is intolerant" (2004:4).

\section{Notes}

1. This article is based on the first chapter of my doctoral research project "Orlando Fals Borda or The Ethics of Subversion: Towards a Critique of Ideology of Political Violence in Colombia, 1948-1974," which I carried out thanks to a University of Roehampton full scholarship for the period 2012-2015. I worked under the supervision of Dr. Carrie Hamilton. For my research, I did two three-month periods of fieldwork in Colombia. There, Dr. Mónica Moreno generously shared archive material obtained for her own research. I express my thanks to the staff of the Archivo Central e Histórico de la Universidad Nacional, Bogotá (ACHUN/B), especially to Gabriel Escalante, whose unconditional help enormously facilitated my work; the Archivo General de la Nación, Bogotá; the Biblioteca de la Universidad Javeriana, Bogotá; the British Library, UK; and the Library of Roehampton University. My greatest debt of gratitude is to Gill for her dedication to the entire final manuscript.

2. Archivo Central e Histórico, Universidad Nacional de Colombia, Fondo Orlando Fals-Borda (ACH-UN, FOFB). Digital. Relaciones_Internacionales, Europa_II_Suiza_05. I use FOFB as an abbreviation for citation purposes.

3. "La primera, que está vinculada con sus estudios de sociología en Estados Unidos y con la creación de la Facultad de Sociología... La segunda, la 'sociología comprometida,' que se inició con La Subversión en Colombia, Visión del Cambio Social en la Historia (1967). La tercera etapa, que comenzó en los años setenta y se prolongó hasta el final de sus días" (Cataño 2008, 79-98). Estas estapas serían: 1) De la realidad a la utopía; 2) La sociología y la realidad sociopolítica colombiana; y 3 ) Investigaciones y vida individual, familiar y política (Vizcaino 2008, 569-594).

4. Geneva, 22 May 1968. ACH-UN, FOFB. Digital. Universidades, Universidad_Nacional_75. The lectures he talked about 
were five lectures delivered by Fals-Borda at the Institute of Latin American Studies London University in 1968. Published in Fals-Borda's Revoluciones Inconclusas de América Latina 1809-1968.

5. Professor Lynn Smith from the University of Florida, one of the most relevant academics on rural sociology in the US, was also involved in both teaching and consultancy of large-scale projects of rural modernisation in Brazil, Ecuador, Peru, Mexico, Cuba, and Panamá.

6. Letter from and to Claudia Wheaton, a donor toward the publication of Fals-Borda's Peasant Society, on 18 and 21 September 1954.

7. Lowry Nelson congratulating Fals-Borda for the completion of his $\mathrm{PhD}$ : "I take pleasure in sending you the hearty congratulations of Mrs. Nelson and myself. Even though your degree was granted by the University of Florida, we shall always claim you as one of our 'children' also." Letter on 30 September 1955.

8. Point IV was a programme established after President Truman's "good will" policy in 1949 for Latin American countries, which implied scientific and technical cooperation.

9. As Fals-Borda wrote to Lynn Smith on 10 April 1957: "My new book is going to press next week. I was very fortunate in having the financial and distribution backing of the editors and printers, in such manner that I have to foot only one third of the bill. This is most unusual in Colombia, where authors have to pay all expenses and distribute the copies themselves." In October that year, Fals-Borda wrote to Smith: "the book has had a 'phenomenal' sale in Colombia (in comparison with other books), as it is being sold at the rate of 100 per month" (FOFB. Universidades, University_Florida_70; 64). The book was revised, re-edited and published again in 1973 with a new introduction. In 2002, after Fals-Borda's Honoris Causa Doctorate, the UPTC published it again.

10. Fals-Borda wrote to Professor Lynn Smith: "The ambassador of the United States ... has expressed his desire to visit Saucío. I had just called the alcalde of Chocontá to let him know, as the date is April 28" (Letter on 10 April 1956; FOFB. Universidades, Florida_54; 82). Lynn Smith himself visited Fals-Borda's project during the summers of 1956, 1957 and 1958.

11. "The farmers' hospitability and agreeableness of nature, their dogged constancy, their hard-working faculties, their objectivity in regard to the practical aspects of life, the sense of security and harmony which they have learned to find in their own neighbourhood, their faith in the Eternal"( Fals-Borda, Peasant Society, 246).

12. Letter to Prof. William F. Ogburn, Department of Sociology, University of Florida on 25 June. From the letter to Lynn Smith on 10 April 1956, it is possible to know that he was teaching a six-week course of sociology at the Alabama College, 18 June-31 July.

13. The sociologist G. Restrepo has suggested a psychoanalytical interpretation of this epigraph. For him, Fals-Borda's identification with Esther reflected Fals-Borda's feeling of guilt since he was criticising the establishment whilst being a public servant. For his criticism, Restrepo referred to the Spanish edition 1961-in which year Fals-Borda was certainly working for the Ministry of Agriculture and the National University. However, he seems to ignore that the book he was talking about was Fals-Borda's MA dissertation, written in 1953 and published in English in 1955 when he was finishing his PhD at the University of Florida (Restrepo 2008, 599).

14. Letter from Henri A., Fals-Borda's student then doing a PhD at Universidad Autónoma de México, on 3 October 1969 (ACHUN, FOFB, Digital. Relaciones Internacional, Bolivia, Cuba, Ecuador,Mexico, Argentina_Mexico_28).

15. "Muchos economistas y profesionales aconsejan la mecanización como si esta fuera una panacea que curara todos los males agrarios. Es probable que la introducción de maquinaria agrícola se justifique en haciendas y tierras planas... pero recomendar[la] a un minifundista, es erróneo" (Fals-Borda 2010, 30).

16. I am referring here to "The Development of the Peasant Individual" and "The Role of Religion in Peasant Life,' respectively. See letters from and to Robert J. Havighurst on 13 February and 8 April 1958 (FOFB. Libros, Peasant_Society_Colombia_15-17). 


\section{Works Cited}

Benjamin, Walter. 2004. "Experience”. 1913. Selected Writings 1913-1926, vol. 1. Edited by Marcus Bullock and Michael W. Jennings. Cambridge, Massachusetts: Harvard University Press.

Cataño, Gonzalo. 2008. “Orlando Fals-Borda, sociólogo del compromiso”. Revista de Economía Institucional, vol. 10, no. 19, pp. 79-98.

Cendales Lola et al, 2005. "One sows the seed, but it has its own dynamics: An interview with Orlando Fals-Borda". International Journal of Action Research 1, no. 1, pp. 9-42.

Díaz, Juan Mario. 2007. “Orlando Fals-Borda or The Ethics of Subversion: Towards a Critique of Ideology of Political Violence in Colombia, 1948-1974”. Doctoral Thesis. University of Roehampton, London.

Fals-Borda, Orlando. 1995. Peasant Society in the Colombian Andes. Gainesville: University of Florida Press. 1959. La Teoría y la Realidad del Cambio Sociocultural en Colombia. Monografías Sociológicas N. 2. Bogotá: Departamento de Sociología Universidad Nacional.

. 1964. "The Role of Violence in the Break with Traditionalism: The Colombian Case" In The Sociologists, the Policy-Makers and the Public. The Sociology of Development. Volume III. Transactions of the Fifth World Congress of Sociology, Washington D. C., 2-8, September. Washington: International Sociological Association.

1995. "Research for Social Justice: Some North-South Convergences'. Plenary Address at the Southern Sociological Society Meeting, Atlanta.

Fondo Orlando Fals-Borda, Archivo Central e Histórico (ACH-UN, FOFB), Universidad Nacional de Colombia, Bogotá.

Goulet, Denis, 1974. A New Moral Order. Studies in Development Ethics and Liberation Theology. Maryknoll, New York: Orbis Books.

Jaramillo, Jaime Eduardo. 2015. "Redes académicas en las ciencias sociales en Colombia: de la Escuela Normal Superior, a la 'Tertulia de los sábados' y a la Facultad de Sociología de la Universidad Nacional de Colombia (1940 - 1970)”. XVII Congreso Nacional de Historia, Bogotá.

Pereira Fernández, Alexánder. 2008. "Fals Borda: La formación de un intelectual disórgano". Anuario Colombiano de Historia Social y de la Cultura 35, pp. 376-411.

Restrepo Gabriel. 2008. "Cuando cae el telón principia la obra: en memoria de Orlando Fals-Borda.” Espacio Abierto vol. 17, no. 4, pp. 595-613.

Rojas Guerra, José María. 2010. Prologue to Antología, by Orlando Fals-Borda (Bogotá: Vicerrectoría Académica Universidad Nacional Editorial.

Vizcaíno, Melciades. 2008. "De la realidad a la utopía: una incursión por las vida y obra de Orlando Fals-Borda”. Cuaderno Venezolano de Sociología, vol. 17, no. 4, pp. 569-594. 